\title{
DESENVOLVIMENTO DE SISTEMA DE MONITORAMENTO REMOTO DE DESEMPENHO E AVALIAÇÃO FÍSICA DE ATLETAS
}

Development of remote performance monitoring system and physical evaluation of athletes

http://dx.doi.org/10.21116/2016.3

\section{MARQUEZINI FILHO, Paulo Afonso}

Faculdade de Jaguariúna

\section{DELGADO NETO, Geraldo Gonçalves}

Faculdade de Jaguariúna

Resumo: A proposta deste trabalho é o desenvolvimento de um sistema para auxílio no monitoramento remoto de desempenho e avaliação física de atletas. O sistema de monitoramento será desenvolvido para atender à necessidade de profissionais de educação física em obter em tempo real os resultados de um ou mais atletas durante os testes de avaliação física, além de suprir as necessidades da possibilidade de monitoramento de atletas nos mais diversos esportes. A descrição do projeto do sistema de monitoramento será desenvolvida através do roteiro crítico de projeto com descrito por Delgado Neto, Alkmin e Silva, Cabral Vieira e Dedini (2010), o roteiro crítico de projeto é todo desenvolvimento em etapas, com informações e explicações, que auxiliam o projetista. As etapas para desenvolvimento do projeto serão dívidas 3 etapas, - Estudo de Viabilidade, realizada através de pesquisa de campo e pesquisa bibliográfica. Projeto Preliminar, através de modelagem e interface, explicações e coletas de dados, construção de um modelo experimental físico, e Projeto Detalhado, onde serão especificadas peças, partes e desenhos para montagem e fabricação. Espera-se com o desenvolvimento do sistema de monitoramento a melhora na coleta de dados, a possibilidade de tornar mais dinâmica a avaliação dos resultados durante atividades físicas e a melhora na interface e integração de sistemas.

Palavras-chaves: Monitoramento remoto; metodologia de projeto; avaliação física.

Abstract: The purpose of this work is the development of a system to facilitate remote monitoring of performance and physical evaluation of athletes. The monitoring system will be developed to meet the need for physical education professionals to obtain in real time the results of one or more athletes during physical assessment tests, as well as meet the needs of the possibility of monitoring athletes in various sports. A description of the monitoring system project will be developed through critical script project described by Delgado Neto, Alkmin e Silva, Vieira Cabral and Dedini (2010), the critical roadmap development project is all in stages, with information and explanations, that assist the designer. The steps for development of the project will be debt 3 steps, the Feasibility Study, conducted through field research and literature review. Preliminary design through modeling and interface, explanations and data collection, construction of a physical experimental model and Detailed Design, where spare parts and assembly drawings for manufacturing and will be specified. It is hoped that the development of the monitoring system to improve data collection, the possibility of making more dynamic evaluation of 
results during physical activities and improved interface and systems integration.

Key-Words: Remote monitoring; project methodology; physical assessment.

\section{INTRODUÇÃO}

Com uma predileção especial pelas práticas esportivas, o brasileiro sua a camisa em muitas modalidades de esporte, mostrando um gosto que vai muito além do futebol, (GURGEL, 2011). Segundo a pesquisa Dossiê Esporte, feito sob encomenda do canal de televisão SportTV, 94\% dos brasileiros se interessam por esporte, considerando os que praticam e os que assistem as atividades esportivas. Do total de participantes da pesquisa, $23 \%$ afirmam praticar esportes sempre, $31 \%$ regularmente, $22 \%$ às vezes e $24 \%$ nunca fazem atividades esportivas. Conforme resultado da pesquisa, $74 \%$ dos brasileiros sabem que o esporte tem relação direta com a saúde e $53 \%$ declararam gostar da sensação de esforço que o esporte proporciona e $48 \%$ procuram um bom condicionamento físico. A avaliação e o acompanhamento de um profissional de educação física são essenciais para as pessoas atingirem os resultados esperados sem riscos. Os educadores físicos, através da avaliação física, podem determinar a condição física e ter parâmetros para verificar a curto, médio ou longo prazo as dificuldades e qualidades de seus alunos. Segundo Trishter (2003), avaliação é realizada através de testes que avaliam a aptidão física, habilidades esportivas, estresse do exercício e lesões esportivas. Para se avaliar primeiro é necessário estabelecer um critério, realizar a coleta e interpretação dos dados e, então fazer o julgamento dos resultados e escolher as possíveis formas de ação. O julgamento dos resultados é realizado através da comparação com diretrizes ou padrões, podendo ser realizadas comparações entre o resultado de duas pessoas, comparação com um critério padrão ou através da comparação com diferentes resultados da mesma pessoa. Os dados são colhidos através do uso de instrumentos de medição que são selecionados levando-se em consideração sua pretensão de uso, exatidão e custo. Para Trishter (2003), os instrumentos de medição devem ter como qualidade a validade, ou seja, integridade e segurança na coleta de dados, fidedignidade, ou seja, consistência na coleta 
de dados, objetividade, ou seja, exatidão e liberdade de tendência em avaliação, ou seja, imparcialidade.

O módulo de monitoramento do sistema pretende ser um instrumento de medição de dados em tempo real que serão enviados via rede sem fio para uma interface computacional a ser utilizado pelo educador físico, e este poderá realizar o julgamento dos resultados durante a avaliação física. O módulo será uma ferramenta que auxiliará na aplicação do teste de aptidão cardiorrespiratória durante a avaliação física ou no monitoramento durante uma atividade.

Para que o educador físico possa se valer dos dados colhidos e através deles fazer julgamento dos resultados, e também para que os dados sejam salvos para consulta futura, promovendo assim a possibilidade de comparações entre os resultados de duas pessoas diferentes ou a possibilidade da comparação de resultados de testes distintos realizados pela mesma pessoa, os dados serão apresentados através de um programa computacional específico conhecido como Supervisório ou Sistema de Supervisão e Aquisição de Dados (SCADA - Supervisory Control and Data Acquisition), (SANDRINI LUZ, 2012). Este programa será executado em um computador pessoal e receberá os dados remotamente e em tempo real através de uma rede de comunicação sem fio. Os sistemas supervisórios são utilizados normalmente em ambiente industrial, onde funcionam como uma ferramenta de interface entre o processo a ser controlado e o operador, provendo a este, os dados relativos ao processo através de gráficos, histórico de eventos importantes e possibilidade de intervenção. Fazendo uma analogia, na nova utilização do programa computacional supervisório em auxilio ao sistema de monitoramento remoto de atletas, este servirá como interface entre o educador físico e o atleta, provendo os dados do atleta relativos ao teste de aptidão cardiorrespiratória através de gráficos, histórico de eventos importantes e possibilidade de intervenção nos testes.

\section{OBJETIVO}

Para auxílio no início do desenvolvimento, e com objetivo de analisar todas as funções que o sistema deve ter para alcançar todos os seus objetivos e também, como forma de analisar as tecnologias que deverão ser 
empregadas, foi desenvolvido e é apresentado na figura 1 o diagrama de bloco do sistema.

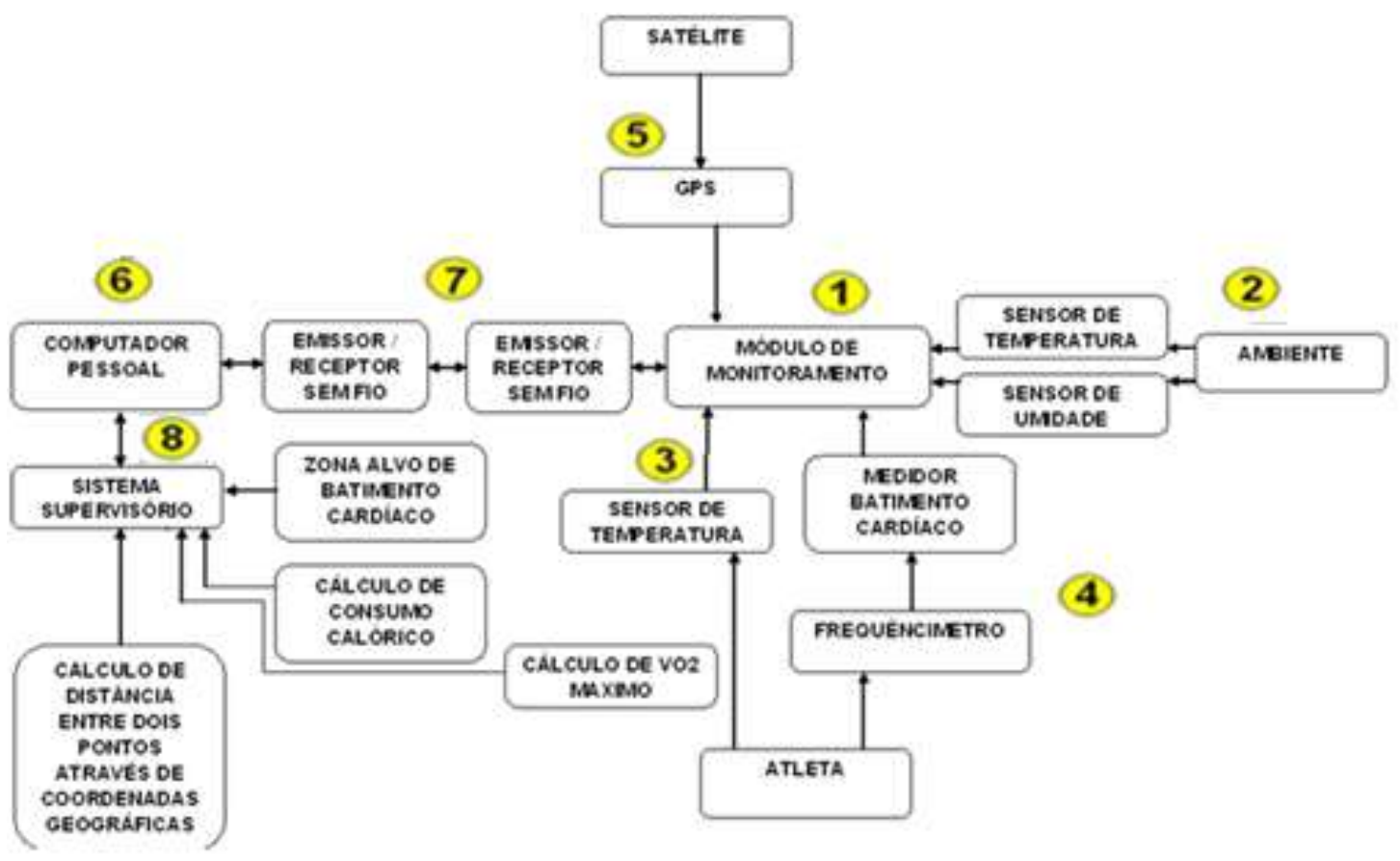

Figura 1 - Diagrama de Blocos

\section{Descrição}

Como pode ser observado no diagrama de blocos da figura 1, o sistema será basicamente um módulo a ser utilizado pelo atleta durante os testes, que enviará as informações via rede sem fio para um computador pessoal onde estará sendo executado o sistema computacional supervisório. No módulo microprocessado, será instalado um sistema GPS responsável por enviar os dados de localização através de coordenadas geográficas, altitude em relação ao nível do mar e velocidade. Também será instalado no módulo um sensor de temperatura e umidade, que serão responsáveis por enviar os dados colhidos do ambiente. No atleta, um sensor será responsável pela leitura da temperatura corporal e um frequêncímetro, fará a leitura da frequência cardíaca, enviando-a a um medidor que enviará os dados ao módulo. O módulo será responsável por tratar os dados e enviá-los via rede sem fio a um computador pessoal, onde os dados serão receptados por um sistema computacional supervisório. No sistema supervisório, serão implementados os cálculos de consumo calórico, zona alvo de batimento cardíaco, cálculo de 
distâncias através de coordenadas GPS. Todo o sistema poderá ser divido em três partes fundamentais: software, hardware e firmware. Hardware são todos os componentes físicos construídos para o sistema de monitoramento, software são instruções geradas para auxílio de interface com o usuário e firmware são instruções geradas para controle de hardware, (FERNANDES, 2002).

\section{Descrição e legenda da Figura 1}

1 - O módulo conterá um microprocessador que terá a tarefa que receber os dados vindos dos sensores e criar um protocolo de comunicação.

2 - Sensores que ficarão em contato direto com o ambiente, permitindo assim que as condições climáticas sejam consideradas nos testes.

3 - A temperatura corpórea do atleta também será medida através de um sensor de temperatura que ficará em contato direto com seu corpo

4 - O frequêncímetro, que também ficará em contato direto com o corpo do atleta, tem por finalidade a medida da frequência de um sinal, (BRAGA).

5 - GPS (Global Positioning System) ou sistema de posicionamento global. O módulo GPS a ser utilizado, uma vez conectado ao satélite, indicará sua posição geográfica através da latitude e longitude, a altura em relação ao nível do mar e a sua velocidade em $\mathrm{km} / \mathrm{h}$. Essas informações serão repassadas ao módulo que as acrescentará às informações ao protocolo de comunicação para que sejam enviadas para o sistema supervisório que realizará o cálculo de distância percorrida através desses dados. $\mathrm{O}$ sistema GPS livremente comercializado tem precisão entre 3 metros a 5 metros.

6 - O computador pessoal será um equipamento padrão IBM PC (Personal Computer) com interface tipo USB (Universal Serial Bus), que será a porta de entrada dos dados recebidos pelo emissor/receptor de rede sem fio.

7 - Para integrar os dados lidos pelo módulo com o computador pessoal, onde estará executando o sistema supervisório que fará a interface como o educador físico e possibilitando liberdade de movimentação do atleta que usará o módulo, será utilizado uma rede de comunicação sem fio para transmissão dos dados

8 - O sistema supervisório, será um software computacional executado em ambiente Windows. Este terá a função de interface com o usuário, onde poderá encontrar de forma organizada todos os dados necessários para o monitoramento.

O sistema a ser desenvolvido terá as funções de aquisição dos dados vindos do atleta, exibição e auxílio do monitoramento pelo educador físico. Considerando os testes realizados pelo atleta como um processo e o educador físico como o operador deste processo, o sistema servirá como interface entre esses. Portanto, será um sistema supervisório, pois possui as características que podem definir um software como tal. 
Nike Running e Adidas miCoach (figura 2) são exemplos softwares similares ao que será desenvolvido, diferenciando pelo fato de que foram desenvolvidos para utilização em dispositivos móveis, como celulares. Ambos são aplicativos para avaliação e acompanhamento do desenvolvimento da saúde de atletas profissionais ou não, utilizando sensores e ferramentas para coletas de dados (RedBull).

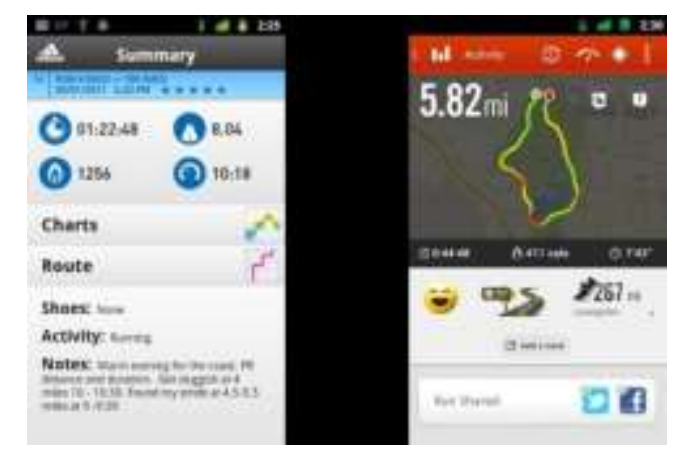

Figura 2 - Nike+ Running e Adidas miCoach

Como poderá ser observado no diagrama de blocos no item Descrição (figura 1), que apresenta as principais funções do sistema de monitoramento, o módulo de monitoramento é responsável por coletar os dados do atleta, enquanto um computador pessoal é responsável pela exibição dos dados ao educador físico, ou seja, será interface entre o sistema e seu operador conforme descrito anteriormente. Para o módulo de monitoramento realizar suas funções como descrito na legenda da figura 1 no item Descrição, é necessário que seja desenvolvido um conjunto de instruções programadas para que tais funções sejam executadas. Estas instruções não servirão como interface ao usuário como foi o caso do software descrito anteriormente, mas realizarão funções ligadas diretamente ao hardware do sistema, portanto estas serão descritas como firmware do sistema.

\section{DESENVOLVIMENTO}

\section{Análise de Necessidade}

Sendo os profissionais de educação física o público alvo de utilização do módulo, foi realizada a Análise de Necessidade conforme Delgado Neto, Alkmin e Silva, Cabral Vieira e Dedini (2008), através de uma pesquisa. Para pesquisa, foi realizado através de um questionário respondido com a colaboração de profissionais de educação física com o objetivo de identificar os instrumentos utilizados e as necessidades mais críticas que os instrumentos 
existentes no mercado atual não atendem. Quanto aos instrumentos mais utilizados, foram levantados os seguintes dados apresentados através do gráfico 1 e as necessidades de mercado apresentadas na tabela 1.

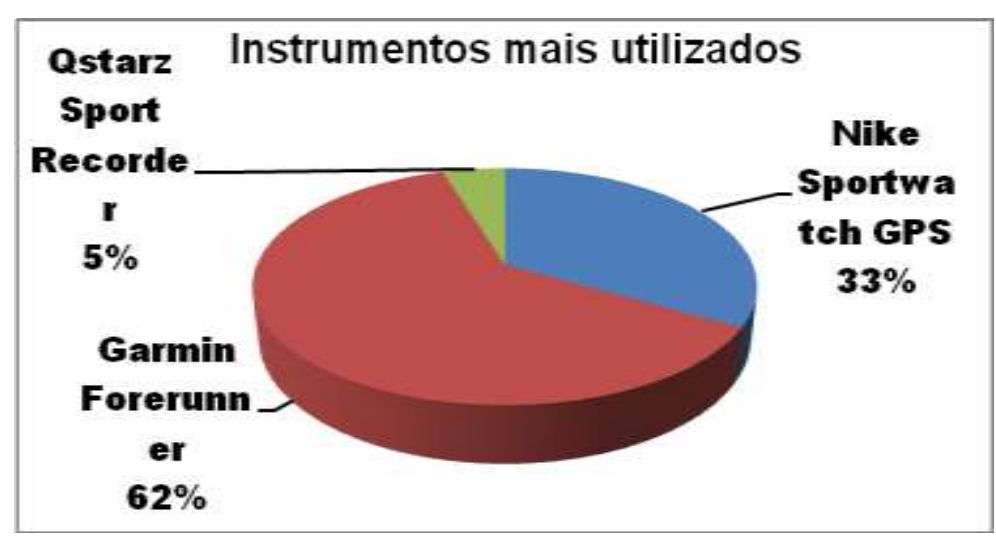

Gráfico 1 - Instrumentos mais utilizados

\begin{tabular}{|ll|}
\hline$\bullet$ & $\begin{array}{l}\text { Precisão no cálculo da distância percorrida, permitindo a utilização em esportes com deslocamentos em } \\
\text { pequenas distâncias. }\end{array}$ \\
\hline$\bullet$ & Leitura dos dados em tempo real. \\
\hline$\bullet$ & Possibilidade de monitoramento de mais de um atleta ao mesmo tempo. \\
\hline$\bullet$ & Autonomia de uso devido à carga da bateria. \\
\hline$\bullet$ & Precisão da leitura de batimento cardíaco. \\
\hline$\bullet$ & Preço. \\
\hline
\end{tabular}

Tabela 1 - Necessidades de mercado

Uma vez levantados os instrumentos mais utilizados no mercado, com as mesmas características a que o módulo a ser desenvolvido se propõe, foi realizada a Análise de Similares conforme Delgado Neto, Alkmin e Silva, Cabral Vieira e Dedini (2008)

As características que existem em comum, as características particulares, os pontos considerados fracos e fortes podem ser consultados na tabela 2 do trabalho de conclusão de curso "Sistema de Monitoramento Remoto de Desempenho e Avaliação Física de Atletas".

Através dos dados levantados pela Análise de Similares e considerando as características, pontos fortes e pontos fracos dos itens analisados, o objetivo do projeto será desenvolvimento do sistema de monitoramento remoto de desempenho e avaliação física de atletas, agregando as principais características disponíveis no mercado, mantendo os pontos 
fortes e procurando soluções para os pontos fracos, possibilitando o uso no sistema nas mais diversas modalidades de esporte.

\section{Explorar Sistemas Envolvidos}

A ferramenta que auxiliará a explorar os sistemas envolvidos que poderão ser incorporados ao módulo é o Mapa Mental conforme figura 4, onde serão mapeados todos os sistemas necessários e opções existentes no mercado. Para desenvolvimento do Mapa Mental foram listados todos os sistemas necessários ao seu funcionamento e depois todas as opções de tecnologias existentes.

Conforme apresentado no Mapa Mental (figura 3), o Módulo de Monitoramento é o componente central do sistema. Este terá a função de captar todos os sinais gerados pelos Sistemas Necessários em seu entorno, tratar esses sinais tornando-os um protocolo, possibilitando assim que os dados sejam interpretados pelo sistema de interface com o usuário.

Quanto aos Sistemas Necessários apresentados no Mapa Mental (figura 3), a Leitura de Batimento Cardíaco terá a função da leitura da freqüência cardíaca e sua transmissão ao Módulo de Monitoramento. A Leitura da Distância Percorrida, Leitura de Altimetria, Leitura de Velocidade, tem a função de medir a distância desde o início até o final do trajeto percorrido pelo atleta, medir a diferença de altura durante seu trajeto e a de medir a velocidade do atleta respectivamente, e o envio das informações ao Módulo de Monitoramento. $\mathrm{O}$ sistema referente à Ergonomia terá a função de possibilitar 0 bem estar ao atleta durante seus treinamentos, preocupando-se com as dimensões e peso dos componentes. O sistema de Fixação tem a função de definir a melhor forma de fixação do Módulo de Monitoramento ao corpo do atleta, possibilitando assim bem estar e facilidade de movimento durante as atividades físicas. Os sistemas de Leitura da Temperatura Corpórea e da Leitura da Temperatura e Umidade do ambiente tem a função da leitura de temperatura em ambos os casos descritos e enviá-las ao Módulo de Monitoramento, tornando-se dados importantes para a interpretação do desempenho do atleta durante suas atividades. O sistema Controlador é aquele que comandará as funções do Módulo de Monitoramento, terá a função de coordenar todas suas atividades, como por exemplo a aquisição dos sinais, tratamento de erros de leitura, montagem do protocolo e coordenação da 
transmissão de dados. O sistema de Interface é aquele responsável por apresentar os dados lidos ao usuário do sistema, é necessário que a apresentação dos dados seja precisa e em tempo real.

O sistema de Transmissão de dados é responsável pela transmissão dos dados através do protocolo de comunicação desde o Módulo de Monitoramento até o sistema de Interface com o usuário. O sistema de Armazenamento de Dados tem a função de armazenar os dados colhidos durante um treinamento, possibilitando assim que estes sejam recuperados posteriormente.

\section{Soluções Alternativas}

Através do auxílio do Mapa Mental (figura 3), foram verificadas todas as soluções alternativas para o projeto, estas foram divididas conforme 0 sistema em que funcionarão. Suas características foram tabeladas e serão confrontadas com as características que o módulo precisa ter para seu funcionamento, auxiliando assim na escolha da melhor opção. Esta tabela pode ser consultada no trabalho de conclusão de curso "Sistema de Monitoramento Remoto de Desempenho e Avaliação Física de Atletas", tabela 3.

\section{Viabilidade Física}

Levando em consideração as possibilidades levantadas através das soluções alternativas, todas as configurações possíveis foram listadas (figura 4) e as possibilidades de construção, levando em conta as configurações, foram reproduzidas.

Diante as possibilidades de configuração, foi realizado o levantamento sobre o tipo de transmissão de dados e como o módulo irá se fixar no atleta levando em conta seu bem-estar durante a prática esportiva, estes foram considerados os itens mais críticos para diante as possíveis configurações. 
Leitura de temperatura ambiente

\begin{tabular}{c} 
Fixação \\
Leitura altimetria \\
\hline Encapsulamento \\
\hline Controlador \\
\hline Ergonomia
\end{tabular}

Armazenamento de Dados
Leitura de umidade ambiente

Temperatura corporal

Velocidade

Módulo de Monitoramento

Distância Percorrida

Interface

Transmissão de Dados

Batimento Cardiaco

\section{Figura 3 - Mapa Mental}

Legenda Mapa Mental:

No Centro : Módulo de Monitoramento

Nas laterais: Sistemas necessários

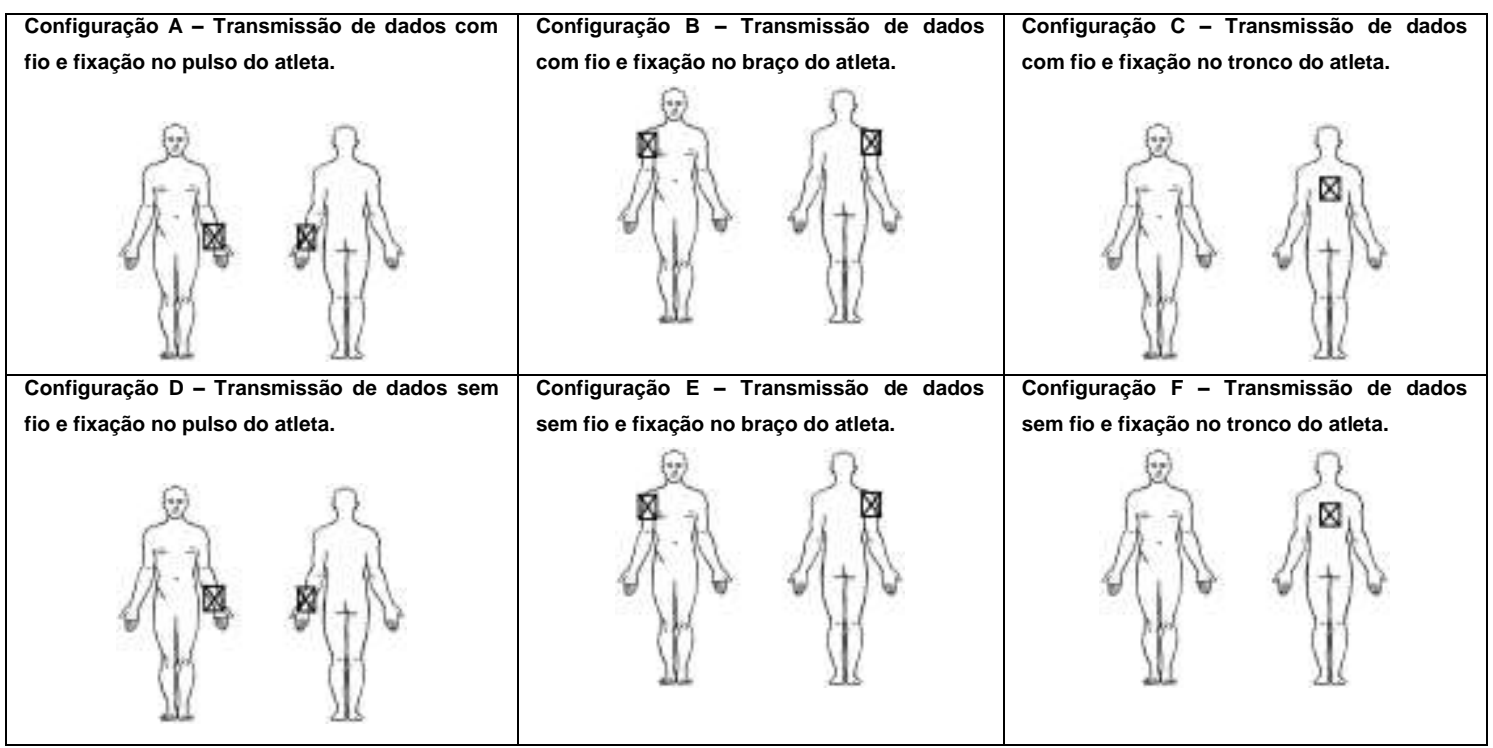

Figura 4- Configurações possíveis

\section{PROJETO PRELIMINAR}

\section{Seleção da Melhor Opção}

Das seis configurações levantadas para o módulo, a escolha da melhor opção, levará em conta somente critérios técnicos de características 
levantadas no item Análise de Necessidade. Grande parte das características já estará presente no módulo, pois fazem parte de sua configuração básica. As características que podem variar dependendo da configuração escolhida são as seguintes:

- Meio de transmissão de dados.

- Quantidade de atletas a serem monitorados ao mesmo tempo.

- Modo de leitura de dados.

Segundo Análise de Necessidade as características que darão ao módulo um diferencial no mercado e, portanto, deverão estar presentes no módulo e serão critérios para escolha, são as seguintes:

- Meio de transmissão de dados sem fio.

- Possibilidade de monitoramento de mais de um atleta ao mesmo tempo.

- Possibilidade da leitura de dados em tempo real.

Levando-se em conta os critérios de escolha, as configurações que atendem as características são as seguintes:

- Configuração D.

- Configuração E.

- Configuração F.

O diferencial entre cada uma das configurações é o ponto de fixação no corpo do atleta. Fica definido a partir de agora que o ponto de fixação será opcional ao usuário, que poderá escolher entre cada um dos três pontos definidos nas configurações dependendo do esporte praticado.

Uma vez definida as configurações a serem adotadas, ficam definidas as alternativas de sistemas que serão utilizados. Porém, conforme tabela 3 , ainda existem opções aos sistemas adotados. A escolha entre as opções seguirá ao critério estabelecido tabela 8 coluna "Requisitos".

\section{Formulação do Modelo Matemático}

O modelo matemático a ser desenvolvido constará das funções lógicas que deverão ser implementadas no sistema computacional e também para controle de hardware com o objetivo que o todo o sistema exerça plenamente as funções pretendidas.

O sistema computacional (software), tem a função de recepcionar todos os dados gerados pelo módulo junto ao atleta, exibi-los na tela do 
computador através de animações e gráficos que auxiliarão o educador físico a diagnosticar o desempenho do atleta durante as atividades físicas. O sistema terá função de armazenar os dados em um arquivo de dados, possibilitando a recuperação dos dados para visualização posterior, para comparação, e geração de relatórios.

O sistema de controle de hardware, a firmware, tem a função da geração de dados e transmissão ao computador pessoal onde está rodando o sistema computacional supervisório (software).

\section{Desenvolvimento do Modelo Matemático}

Neste tópico serão apresentados as funções do software e firmware no sistema de monitoramento de atleta, e os métodos utilizados para construção dessas funções.

\section{Funções do Software}

O software desenvolvido para o sistema de monitoramento será executado em um computador pessoal que será utilizado pelo profissional de educação física. Este terá as funções de recepção, interpretação do protocolo de comunicação, tratamento e exibição dos dados transmitidos pelo módulo de monitoramento ao educador físico. As funções do software podem ser vista no diagrama de blocos da figura 5.

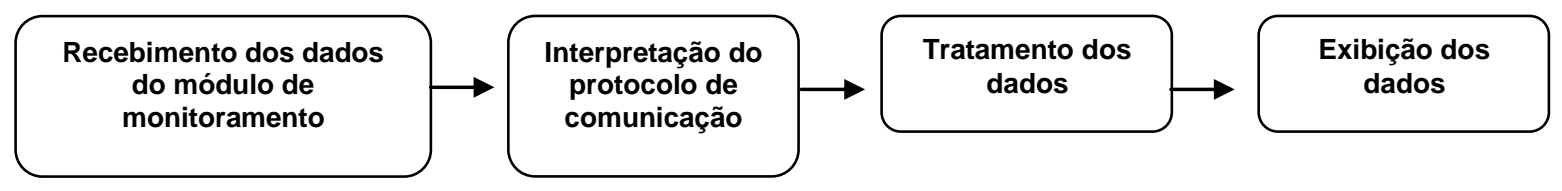

Figura 5 - Diagrama de blocos das funções do software

\section{Funções do Firmware}

O firmware desenvolvido para o sistema de monitoramento será executado no módulo de monitoramento que ficará fixo ao atleta. Este terá as funções de coleta dos dados gerados pelos sensores fixos ao atleta, tratamento, montagem do protocolo de comunicação e transmissão dos dados ao computador pessoal utilizado pelo educador físico (figura 6). 


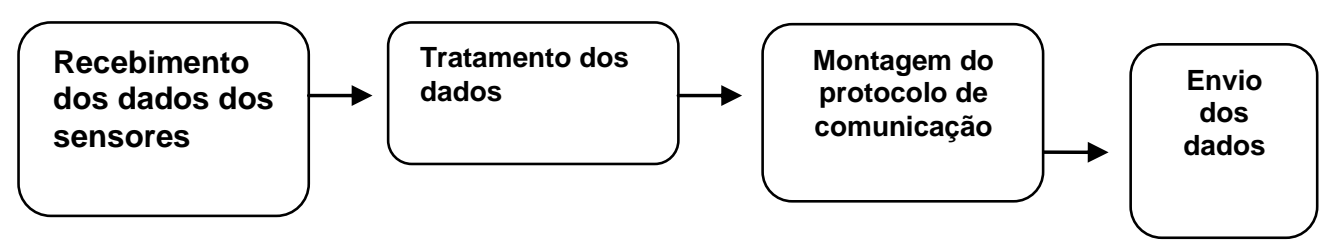

Figura 6 - Diagrama de blocos das funções do firmware

\section{Protocolo de comunicação}

O protocolo é uma regra de comunicação entre o firmware do módulo de monitoramento e o software executado em um computador pessoal. Nele são carregados os dados do módulo de monitoramento até o computador. Somente um sistema capaz de montar ou interpretar o protocolo, poderá compartilhar ou receber os dados transmitidos pelo sistema. A regra ou protocolo criado para o sistema constam de um conjunto de caracteres onde os dados estão inseridos. Esta regra será criada pelo módulo de monitoramento através de sua firmware e interpretado pelo computador através de seu software. O protocolo criado por ser visto na figura 7 .

\section{AN0:0055:TMP:0151:BAT:068:VEL:000.00:ALT:0220.00:LAT:- \\ 22.44283:LOG:-046.81641:TEMPER:24:UMI:38:BIT:00000111:FIM}

\section{Figura 7 - Protocolo de comunicação}

\section{Legenda da figura 7:}

AN0:0055 - ANO é o cabeçalho do protocolo de comunicação, estes caracteres são a primeiro identificação do protocolo de comunicação, e indicarão para o receptor do protocolo (software) que a transmissão de dados foi iniciada. $O$ valor "0055" indica um valor vindo de uma das entradas do micro-controlador do sistema de monitoramento, sem função.

TMP:0151 - TMP indica que o próximo valor corresponde ao sensor de temperatura que será responsável pela leitura da temperatura corporal do atleta.

BAT:068 - BAT indica que o próximo valor corresponde ao sensor que mede o batimento cardíaco do atleta.

VEL:000.00 - VEL indica que o próximo valor corresponde a velocidade atual do atleta. 
ALT:0220.00 - ALT indica que o próximo valor corresponde a altura atual do atleta em relação ao nível do mar.

LAT:-22.44283 - LAT indica que o próximo valor corresponde a latitude da posição geográfica atual do atleta.

LOG:-046.81641 - LOG indica que o próximo valor corresponde a longitude da posição geográfica atual do atleta.

TEMPER:24 - TEMPER indica que o próximo valor corresponde a temperatura do ambiente onde está o atleta.

UMI:38 - UMI indica que o próximo valor corresponde a umidade do ambiente onde está 0 atleta.

BIT:00000111 - BIT indica que os próximos valores binários indicam estado de comunicação com os sensores de batimento cardíaco, temperatura e umidade do ambiente e GPS dos sistema.

FIM - FIM indica o final do conjunto de caracteres, ou seja, o final do protocolo de comunicação.

":" - Os dois pontos servem como separadores de cada informação transferida.

Como pode ser observado na figura 7 , o protocolo é um conjunto de caracteres com as informações pertinentes ao sistema inseridos em lugares determinados. Como será visto adiante, a montagem do protocolo pelo firmware, será a montagem deste conjunto de caracteres e, a interpretação do protocolo pelo software, será a extração das informações contidas no conjunto de caracteres. A utilização do protocolo, além de auxílios funcionais para o sistema, proporciona segurança, uma vez que somente sistemas programados a interpretação dos dados, terão acesso aos mesmos.

\section{Descritivo para construção das funções do Software}

\section{Recebimento de dados vindos do módulo de monitoramento}

Como foi visto em anteriormente, os dados chegarão ao software através do protocolo de comunicação. Cada caracter do protocolo será enviado pelo módulo de monitoramento e chegará de maneira serial para o software, ou seja, um de cada vez, um após o outro. Portanto, para o recebimento, primeiro é necessário que o software receba cada caracter individualmente e monte um 
conjunto de caracteres, formando assim todo o protocolo de comunicação. Como será visto posteriormente, o protocolo de comunicação terá a quantidade de 112 caracteres, característica providenciada por funções do firmware do módulo de monitoramento. E também sempre será iniciado pelos caracteres "ANO" e finalizado pelos caracteres "FIM". Portanto, o recebimento de dados vindos do módulo de monitoramento devem ser realizados conforme descrito abaixo:

- CADA CARACTER RECEBIDO PELO SOFTWARE DEVE SER ARMAZENADA EM UM VARIÁVEL DO TIPO CARACTER.

- CADA CARACTER RECEBIDO DEVE SER INCREMENTADO EM UMA VARIÁVEL TIPO CONJUNTO DE CARACTERES.

- A CADA NOVO CARACTER RECEBIDO PELO SOFTWARE DEVE SER TAMBÉM INCREMENTEADO NA VARIÁVEL TIPO CONJUNTO DE CARACTERES.

- QUANDO A VARIÁVEL CONJUNTO DE CARACTER ESTIVER A QUANTIDADE DE 112 CARACTERES, ESTÁ DEVERÁ DEIXAR DE SER INCREMENTADA.

- DEVERÁ SER COMPARADOS OS TRES PRIMEIROS CARACTERES E OS TRES ÚLTIMOS CARACTERES NA VARIÁVEL COM "ANO" E "FIM" RESPECTIVAMENTE.

- CASO OS CARACTERES SEJAM IGUAIS, SIGNIFICA QUE O PROTOCOLO DE COMUNICAÇÃO FOI RECEBIDO CORRETAMENTE.

- CASO OS CARACTERES SEJAM DIFERENTES, SIGNIFICA QUE O PROTOCOLO DE COMUNICAÇÃO NÃO FOI RECEBIDO CORRETAMENTE. PORTANTO, É PRECISO QUE AS INFORMAÇÕES TRANSMITIDAS SEJAM IGNORADAS DEVIDO A UM ERRO DE COMUNICAÇÃO.

Interpretação do protocolo

Uma vez recebido o protocolo de comunicação, a próxima função do software é a de realizar a interpretação dos dados, ou seja, interpretar os dados contidos nos protocolo. Para isso, será utilizado o caracter ":", que serviu 
no protocolo de comunicação como separador das informações. Observando a figura 14, o protocolo de comunicação será divido e numerado, levando - se em conta a separação de cada informação pelo caracter ":".

$\begin{array}{rrrrrrrrrrrrr}0 & 1 & 2 & 3 & 4 & 5 & 6 & 7 & 8 & 9 & 10 & 11 & 12 \\ 13 & & 14 & 15 & 16 & 17 & 18 & 19 & & 20 & & & \end{array}$

AN0:0055:TMP:0151:BAT:068:VEL:000.00:ALT:0220.00:LAT:-

22.44283:LOG:-046.81641:TEMPER:24:UMI:38:BIT:00000111:FIM

Figura 8 - Protocolo de comunicação com as informações divididas

Pode -se observar na figura 8 que cada dado pertinente corresponde a um valor no protocolo, este valor pode ser obtido utilizando uma função de separação de caracteres de acordo com um caracter de referência, no caso o caracter ":". Portanto para realizar a função de tratamento dos dados, é necessário desenvolver uma rotina conforme descrita abaixo:

- A VARIÁVEL DO TIPO CONJUNTO DE CARACTERES QUE CONTÉM O PROTOCOLO DE COMUNICAÇÃO DEVERÁ SER DIVIDIDA UTILIZANDO COMO REFERÊNCIA O CARACTER “:”.

- CADA CONJUNTO DE CARACTERES ORIGINÁRIOS DESTA DIVISÃO, DEVERÁ SER ALOCADO EM OUTRAS VARIÁVEIS DO TIPO CONJUNTO DE CARACTERES .

\section{Tratamento dos dados}

Os dados recebidos e interpretados, agora precisam ser tratados. Algumas informações, depois de interpretadas, já estão prontas para uso. Porém em outras, é necessário seu tratamento para exibição correta da informação que contém, como é o caso da temperatura corporal do atleta. Esta vem em uma escala de 0 à 1023, porém está informação contém temperatura entre $0^{\circ} \mathrm{C}$ a $50^{\circ} \mathrm{C}$. Para que seja exibida corretamente, é necessário tratar esta informação através de uma função matemática.

A função matemática a ser utilizada por ser vista abaixo:

$Y=(50 / 1023)^{\star} X$, onde $X=$ informação entre 0 a 1023, $Y=$ informação entre 0 a 50 
Portanto, é necessário desenvolver no software uma rotina conforme descrito a seguir:

- A VARIÁVEL QUE CONTEM A INFORMAÇÃo DE TEMPERATURA DEVERÁ SER CONVERTIDA DO TIPO CONJUNTO DE CARACTERES PARA O TIPO NUMÉRICO.

- A VARIÁVEL do TIPO NUMÉRICO QUE CONTÉM A INFORMAÇÃO DA TEMPERATURA DEVERÁ SER INSERIDA NA FORMULA ACIMA E SEU RESULTADO ARMAZENADO EM UMA NOVA VARIÁVEL DO TIPO NUMÉRICO.

\section{Exibição dos dados}

Uma vez os dados tratados, será necessário exibi-los para o usuário. A exibição de dados se dá através de ferramentas visuais que auxiliam o usuário em sua interpretação. A utilização de ferramentas visuais se dá através de parametrização de alguns de seus parâmetros. Para alguns dados serão utilizados gráficos, outros serão utilizados gauges, animações de imagem e outros serão utilizados caixas de texto.

Fluxograma para construção das funções do software (figura 9)
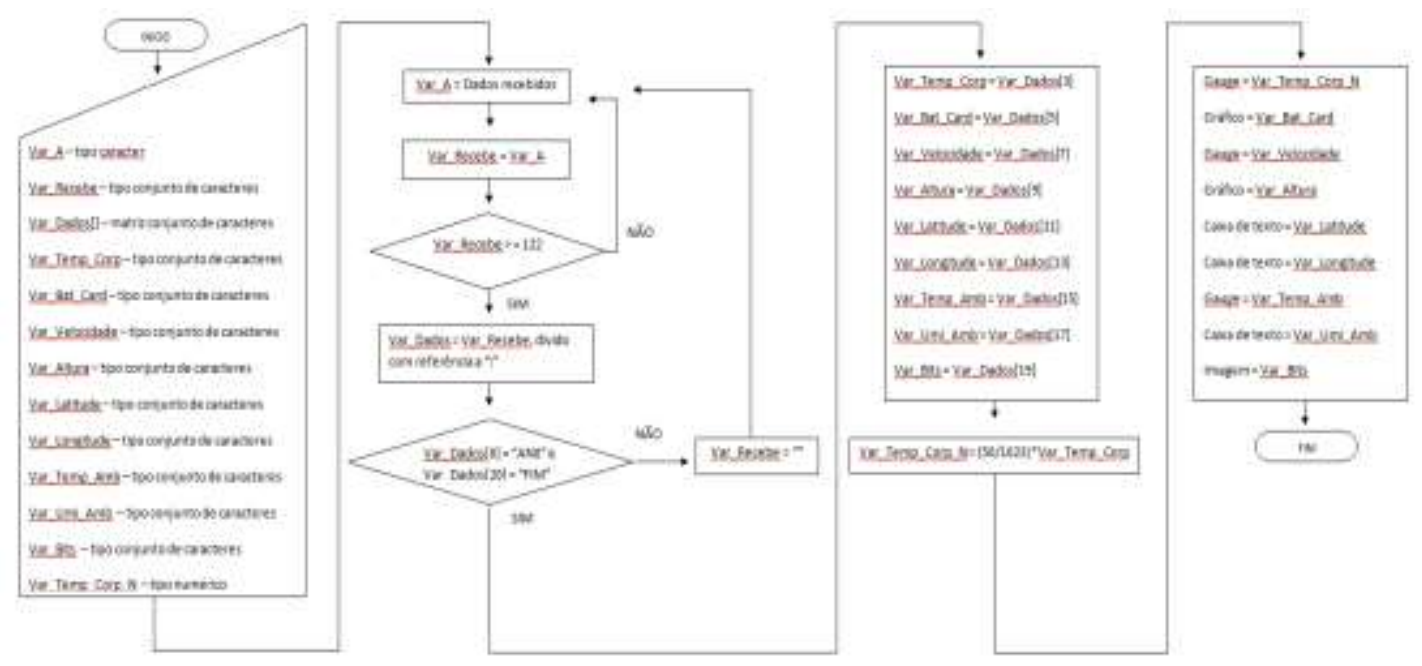

Figura 9 - Fluxograma para construção do software 
Descritivo para construção das funções do Firmware

Recebimento de dados

Uma das funções do firmware quando executado no módulo de monitoramento é a requisição e recebimento dos dados gerados pelos sensores. Os dados gerados deverão ser recebidos pelo módulo de monitoramento, a rotina a ser escrita no firmware para execução desta função é descrita abaixo:

- OS DADOS RECEBIDOS DEVERÃo SER ARMAZENADOS EM MEMÓRIAS. PARA CADA DADO, UMA MEMÓRIA .

Tratamento dos Dados

Os dados recebidos e alocados em memória necessitam ser tratados. O tratamento consta de fazer com que cada dado tenha sempre o mesmo tamanho de caracteres, fazendo com que o protocolo de comunicação também sempre tenha o tamanho de 112 caracteres, facilitando assim as funções do software conforme descrito anteriormente. Abaixo será descrito a rotina que se repetirá para todos os dados, tomando como exemplo o recebimento dos dados de batimento cardíaco.

- OS DADOS dO BATIMENTO CARDíaCO DEVERÃO SEMPRE TER O TAMANHO DE TRÊS CARACTERES, PORTANTO CASO O DADO TENHA O VALOR MENOR QUE 100, ESTE DEVERÁ SER COMPLETADO DE UM CARACTER "0". CASO O DADO TENHA O VALOR MENOR QUE 10, DEVERÁ SER COMPLETADO DE DOIS CARACTERES "0".

Montagem de protocolo de comunicação

A montagem do protocolo de comunicação é a alocação de cada um dos dados no formato conforme descrito no item "Protocolo de Comunicação". Abaixo segue a descrição do procedimento para montagem do protocolo.

- os dados deVERÃo ser alocados na sequÊncia CONFORME DESCRITO NO ITEM "PROTOCOLO DE COMUNICAÇÃO" E DEVERÃO SER ACRESCENTADOS OS CABEÇALHOS DE CADA UM DOS DADOS, OS CARACTERES QUE MARCAM O INÍCIO E O SEU FIM, COMO TAMBÉM O CARACTER DE 
SEPARÃO QUE AUXILIARÁ NO MOMENTO EM QUE O SOFTWARE FARÁ O TRATAMENTO DOS DADOS.

Envio dos dados

Uma vez o protocolo de comunicação formado, este deverá ser enviado para o computador que fará sua recepção. Para o envio, deverá ser programada uma rotina no firmware conforme abaixo.

- o protocolo deVerá ser alocado em uma memória AUXILIAR E ENVIADO ATRAVÉS DE UMA FUNÇÃO DE ENVIO ESPECÍFICA DA LINGUAGEM UTILIZADA.

Fluxograma para construção das funções do firmware (figura 10)

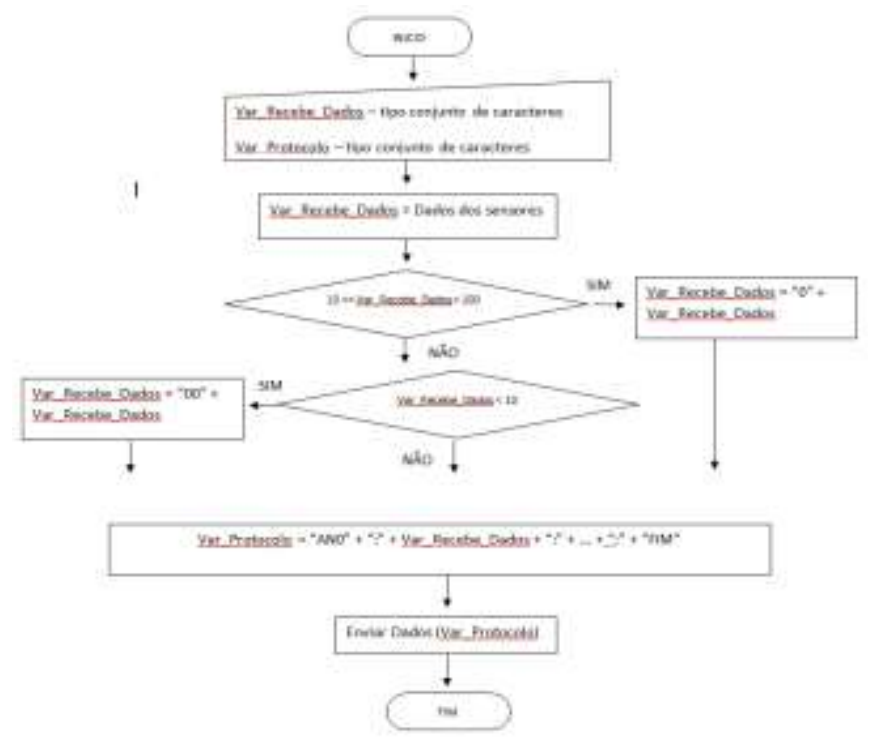

Fluxograma 10 - Fluxograma para construção do firmware

\section{Sensibilidade e Compatibilidade}

A compatibilidade de todos os componentes, ou seja, a interconexão de todos ao projeto de modo que cada um exerça sua função para que o sistema realize tudo o que é pretendido e sua sensibilidade ao projeto, ou seja, a verificação que suas funções são exercidas dentro de um limite pré estabelecido, serão verificadas através de processos de validação. Para o processo de validação, será montado um protótipo do módulo (figura 11), onde todos seus componentes serão conectados. E para este, será desenvolvido um 
código de programação para firmware e software, atendendo os requisitos especificados no item Formulação do Modelo Matemático.

Para auxilio na validação do sistema, deverá ser criada uma lista de todas as funções que deverão ser ensaiadas, assim como o resultado pretendido, levando - se em conta as funções de cada um dentro do projeto, como também a precisão de cada componente.

O resultado de cada análise será verificado através dos testes de validação de Firmware e Software, onde serão exibidas as leituras de cada um. A descrição das validações pode ser vista no trabalho de conclusão de curso "Sistema de Monitoramento Remoto de Desempenho e Avaliação Física de Atletas" no item Sensibilidade e Compatibilidade.

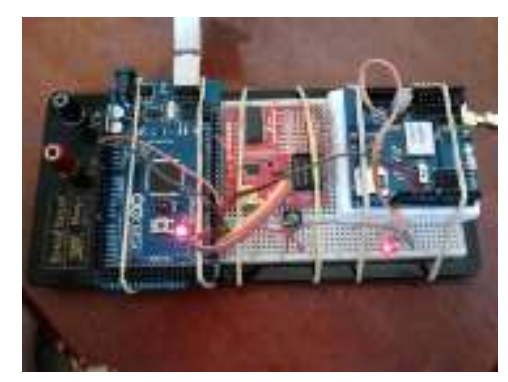

Figura 11 - Protótipo do Módulo de Monitoramento

\section{Otimização dos Parâmetros}

Como pode ser observado na tabela 10 do trabalho de conclusão de curso "Sistema de Monitoramento Remoto de Desempenho e Avaliação Física de Atletas", dois dos itens tiveram algumas observações a respeito de seus desempenhos: o Sensor de Temperatura Corporal e o módulo GPS. Quanto ao Sensor de Temperatura Corporal, observou que o mesmo apresentou variação em sua leitura e ocorreu um desvio ao padrão do Sensor de Temperatura Ambiente que serviu como referência. Já o módulo GPS observou que no inicio de sua conexão ao satélite em ambientes fechados, apresenta um tempo para estabilização de sua leitura o que pode levar ao erro de algumas funções de software que dependam de suas informações.

Para otimização da leitura do Sensor de Temperatura Corporal, será acrescentado ao software à fórmula 1, onde um parâmetro de ajuste será 
somado ao seu dado de leitura, visando assim suprir o erro em relação do Sensor de Temperatura Ambiente.

$$
\text { Var_Temp_Corp_N } \left.=((50 / 1023))^{*} \text { Var_Temp_Corp }\right)+ \text { AJ }
$$

Onde,

Var_Temp_Corp = leitura da temperatura corporal de 0 a 1023

$\mathrm{AJ}=$ ajuste de temperatura para correção de erro de leitura

Var_Temp_Corp_N = leitura da temperatura corporal de 0 a $50 \stackrel{\circ}{ } \mathrm{C}$

\section{Fórmula 1 - Correção da Leitura de Temperatura}

Quanto ao módulo GPS, a característica descrita acima foi observada principalmente em sua utilização em ambientes fechados que podem prejudicar sua conexão com os satélites fazendo com o referido tempo de estabilização ocorra, porém esta é uma característica do módulo utilizado. Para este será acrescida a informação quanto a esta característica, indicando que seja preferencialmente utilizado em ambientes abertos ou, no caso da utilização em ambientes fechados, que a presença do erro que poderá ocorrer.

\section{Testar Processo Prever Desempenho}

A utilização do módulo se dará estando este fixado ao corpo do atleta que estará distante do computador receptor dos dados, em movimento e também variando de posição constantemente. Este é o processo a ser desenvolvido pelo módulo e seu desempenho que será testado.

Para realizar testes de desempenho simulando o processo que será realizado, o protótipo montado foi fixado ao corpo de uma pessoa e 0 computador receptor dos dados instalado em local determinado. A pessoa participante dos testes realizou exercícios de caminhada e corrida, alterando sua posição em relação do receptor por um trajeto pré - determinado. O local de realização dos testes, como também o posicionamento do computador receptor e o espaço de movimentação da pessoa participante dos testes pode ser vista na figura 12. 


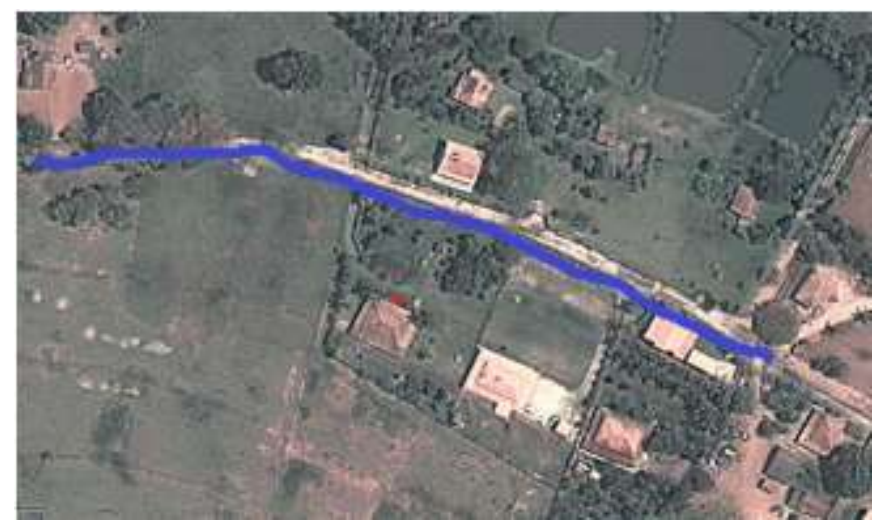

Figura 12 - Local de Testes

Legenda:

Posicionamento do receptor e computador com software de monitoramento

Trajeto percorrido durante os testes

Durante o teste os dados foram enviados pelo módulo ao seu computador receptor. Espera - se que nenhum dos dados sejam perdidos durante a transmissão e que o formato do protocolo de comunicação não seja perdido devido à falhas de sensores ou transmissão.

Os dados chegaram ao computador receptor mantendo o formato do protocolo ou sem a perda de qualquer dado. Portanto, verifica - se que o sistema tem o desempenho esperado, enviando e recepcionando os dados mesmo que em movimento e com alteração constante de movimento.

Uma vez selecionado as melhores opções dos componentes a serem utilizados, formulado o modelo de funcionamento, verificada a sensibilidade e compatibilidade dos componentes, trabalhada a otimização de parâmetros e testado os processos a serem realizados procurando prever seu desempenho, o projeto preliminar está finalizado e o próximo passo é o detalhando do projeto.

\section{PROJETO DETALHADO}


O projeto detalhado do sistema de monitoramento pode ser consultado no trabalho de conclusão de curso "Sistema de Monitoramento Remoto de Desempenho e Avaliação Física de Atletas".

\section{PRODUTO FINAL}

Módulo de Monitoramento e Recepção de dados (figura 14)

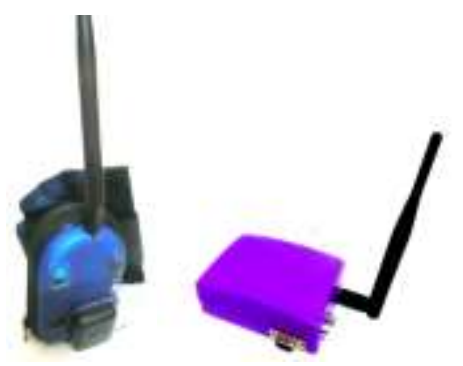

Figura 14 - Módulo de monitoramento e recepção de dados

Software de monitoramento (figuras 15 à 18)

\section{Software de Supervisão}

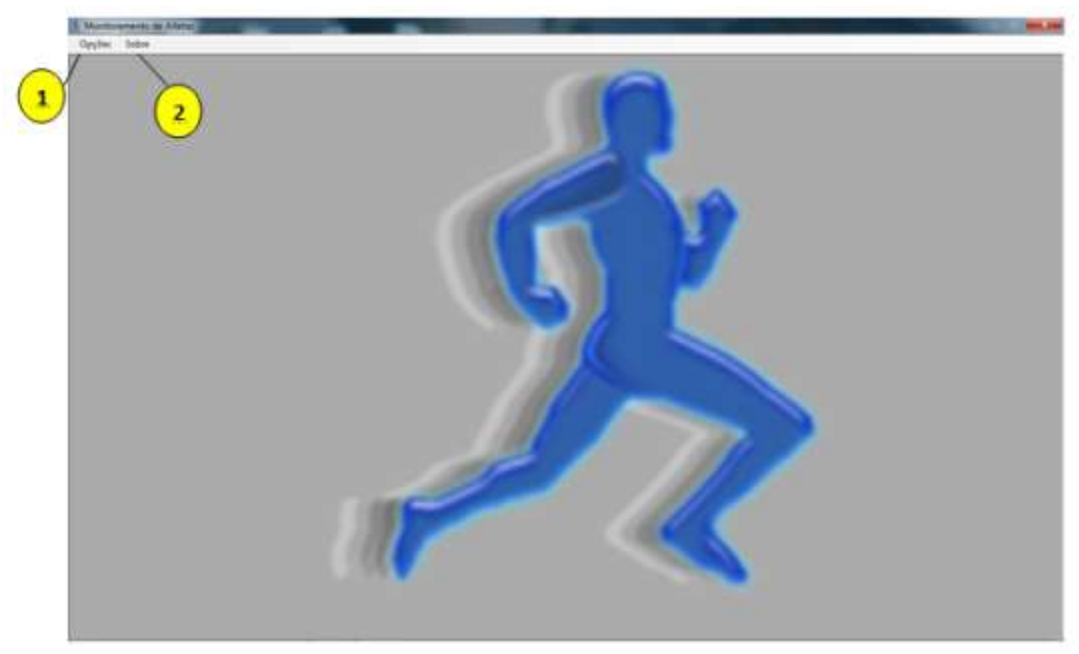

Figura 15 - Tela inicial software de supervisão

Legenda:

1 - Menu de opções

2 - Informações do software 


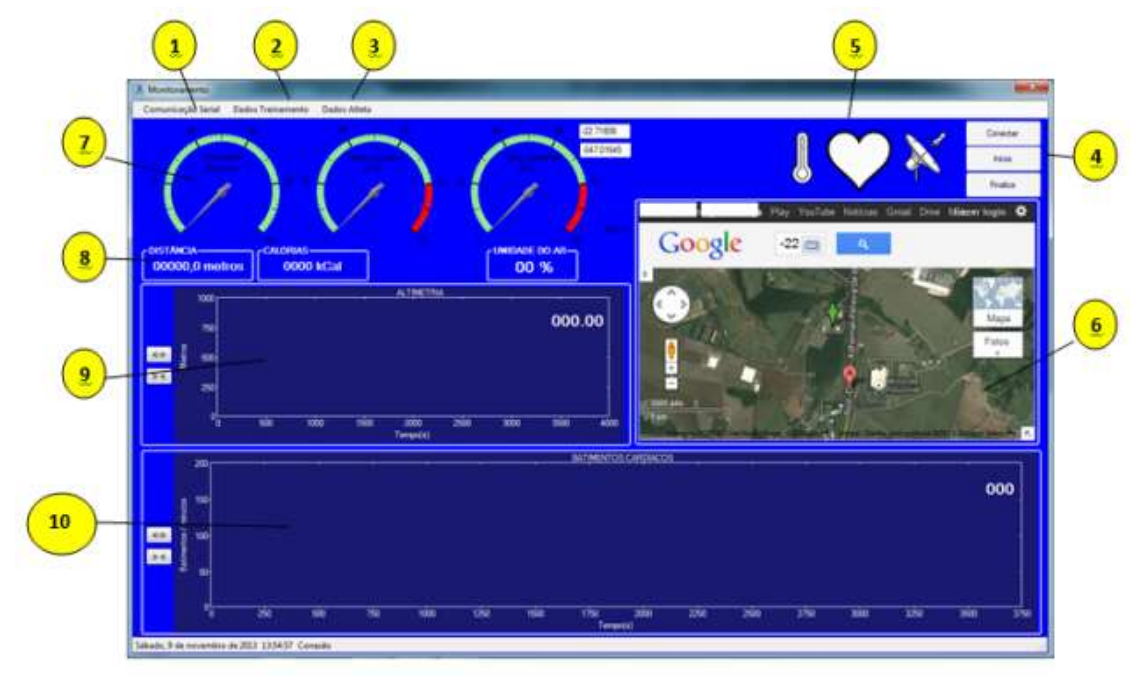

Figura 16 - Tela de monitoramento

Legenda:

1 - Menu de configuração de comunicação

2 - Menu para salvação dos dados do treinamento

3 - Menu para acesso ao formulário de inserção dos dados do atleta

4 - Botões para inicio e fim de comunicação e treinamento

5 - Animações para estado de leitura do GPS, batimento cardíaco e sensor de temperatura e umidade

6 - Mapa com posição atual do atleta

7- Animações para velocidade, temperatura corporal do atleta e umidade e temperatura ambiente

8 - Cálculos de distância percorrida e calorias

9 - Gráfico da altimetria

10 - Gráfico do batimento cardíaco

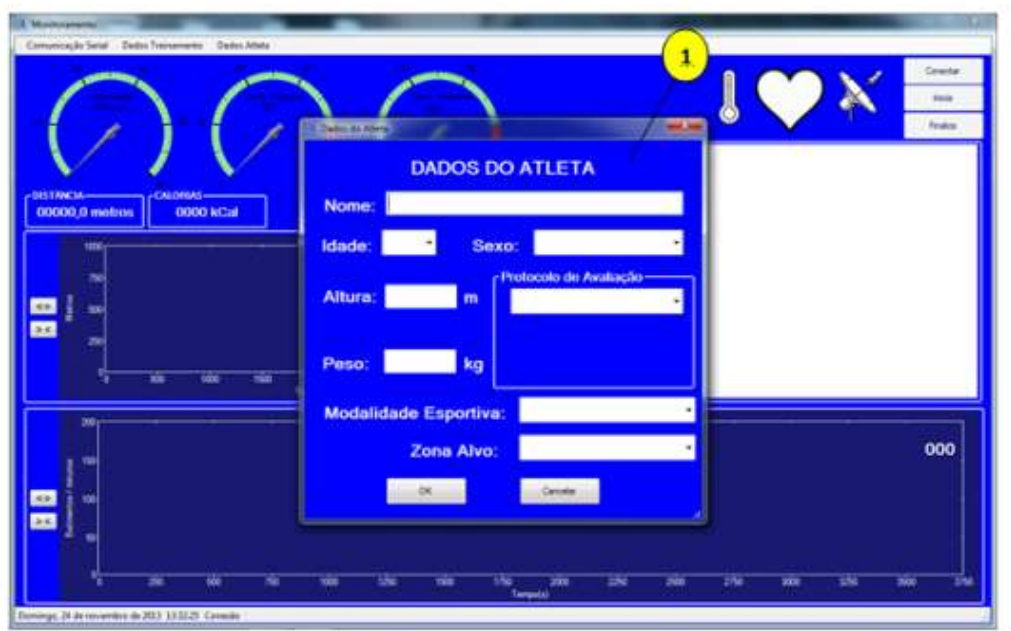

Figura 17 - Tela de dados do atleta

Legenda:

1 - Formulário para inserção dos dados do atleta 


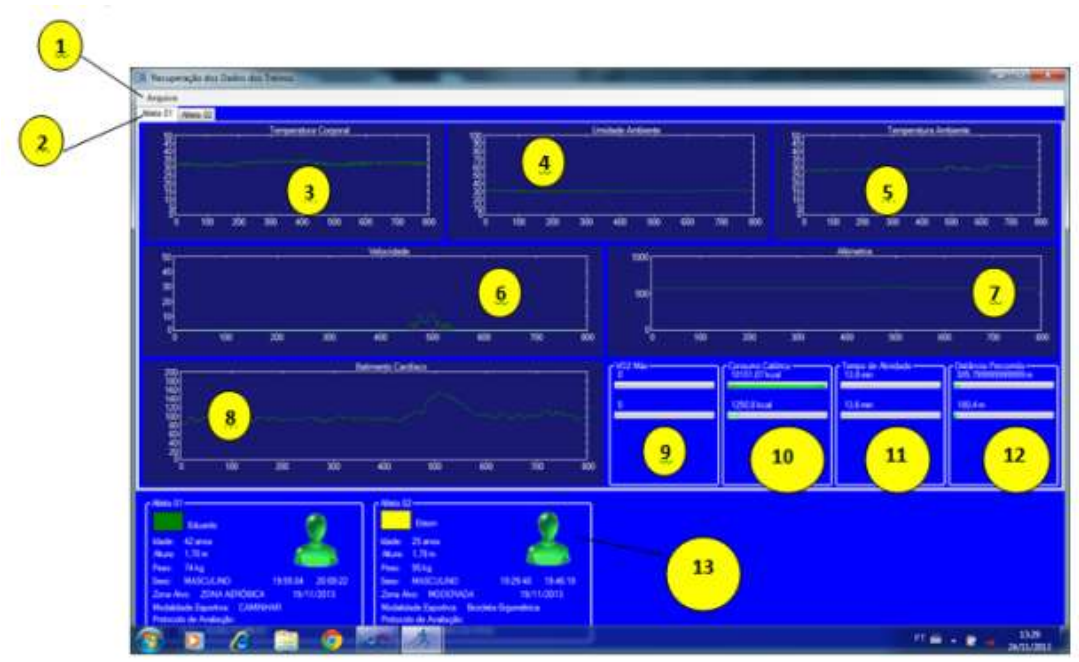

Figura 18 - Tela de recuperação dos dados

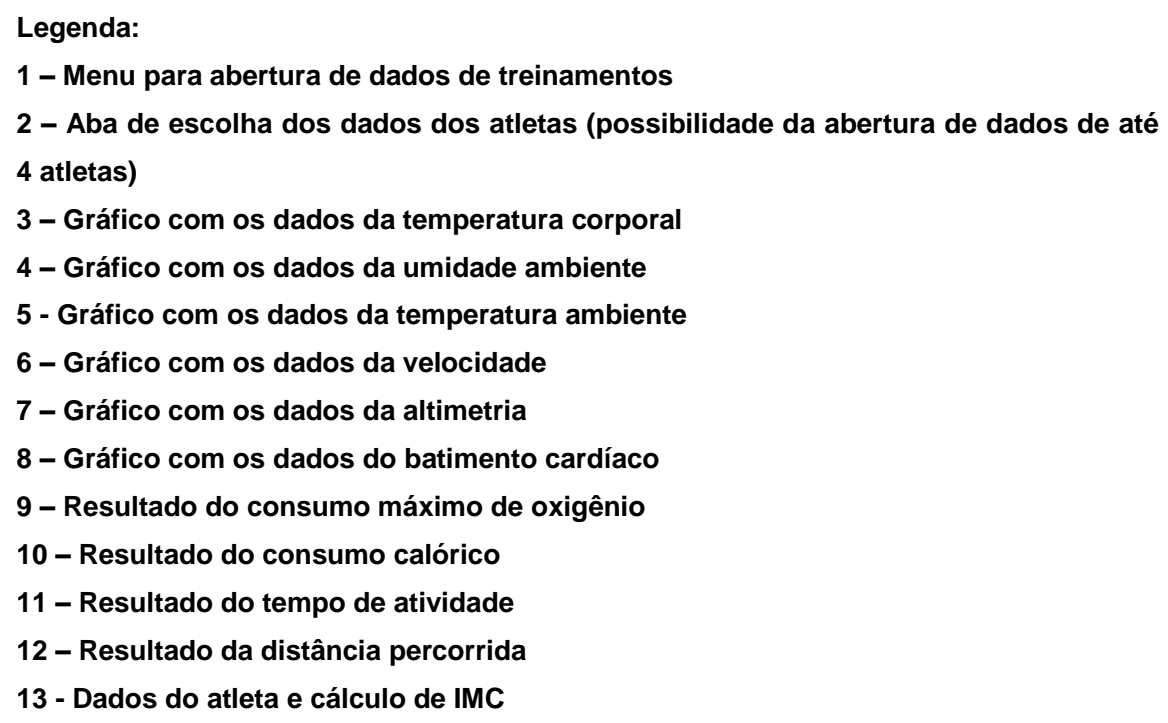

\section{CONSIDERAÇÕES FINAIS}

Quanto ao sistema de monitoramento de atletas desenvolvido, o sistema de transmissão de dados sem fio, mostrou estabilidade mesmo que à longa distância e em movimento. O sistema de leitura de batimento cardíaco mostrou precisão de funcionamento. O sensor de temperatura e umidade mostrou funcionamento satisfatório. O sistema GPS utilizado mostrou restrição ao uso pretendido devido precisão de 5 metros, que não é satisfatória para utilização para monitoramento de atletas em praticas de esporte cujo movimento na maioria das vezes não seja superior a esta distância, também seu uso em ambiente fechado mostrou demora na conexão e imprecisão, o que causou grande variação até que o sistema se estabilizasse com o satélite, 0 
que trouxe como conseqüências erros em medições e cálculos que dependiam de seus dados. O sensor de temperatura, utilizado para leitura da temperatura corporal, apresentou grandes variações de medição, devido à precisão do canal analógico do microcontrolador, somado a possíveis variações da tensão de alimentação do sensor. O software de monitoramento apresentou bom funcionamento de suas animações, cálculos realizados, recepção, salvamento e recuperação de dados. Quanto ao método de desenvolvimento de projeto adotado, este se mostrou uma ótima ferramenta de desenvolvimento, auxiliando para que os objetivos do projeto fossem muito bem definidos e atingidos. A Análise de Necessidade ajudou a levantar as expectativas de possíveis usuários do Sistema de Monitoramento quanto à características e funcionabilidades que acreditam serem necessárias e que ainda não existem no mercado. A Análise de Similares auxiliou na comparação de produtos similares àquele que seria desenvolvido e que já estão disponíveis no mercado, possibilitando à comparação de funcionabilidades e auxiliando no levantamento de características que poderiam ser implementadas como um diferencial. Explorando os Sistemas Envolvidos no projeto, através da ferramenta do Mapa Mental foi um auxilio a definir as varias opções que poderiam ser adotadas para atender todas as características e funcionabilidades que o Sistema de Monitoramento de Atletas deveria ter, e verificando as Soluções Alternativas, poder definir a melhor opção existente. Com a Formulação do Modelo Matemático pode - se projetar as fórmulas e lógicas que dariam as funções ao Sistema de Monitoramento através da execução de seu Firmware e Software. Com a Sensibilidade e Compatibilidade do projeto pode - se prever o desempenho dos diversos módulos que compõe todo o sistema, prevendo seu funcionamento e caso não satisfatório, reverem seus processos a fim de chegar ao resultado necessário. A etapa do Projeto Detalhado permitiu que fossem gerados toda a documentação para que o produto projetado fosse produzido e replicado.

Foi atingido o objetivo do Sistema de Monitoramento de Atletas com poucas ressalvas, o módulo de monitoramento foi capaz de enviar os dados ao módulo de recepção mesmo que em movimento e a grandes distâncias. Conforme discutido no item "Resultados", as ressalvas existentes dizem respeito do módulo GPS e do sensor de leitura de temperatura corporal. 
Quanto ao módulo GPS adotado para o projeto, este é do tipo mais ofertado no mercado, como objetivo de utilização geral e não especifico para o tipo de aplicação que foi implementado. A precisão de 5 metros de leitura de posicionamento geográfico do módulo atende muito bem a aplicações da utilização do GPS como, por exemplo, para navegação em automóveis, onde uma variação 5 metros não influenciará em seu funcionamento e onde na maior parte do tempo ficará em ambiente aberto. Portanto, uma melhoria do Módulo de Monitoramento é a implementação de um sistema GPS com maior precisão e que não tenha seu funcionamento influenciado pelo ambiente em que trabalhará. Outra ressalva do projeto foi o funcionamento do sensor de temperatura, que apresentou variações constantes, esta característica encontrada poderá ser sanada através da utilização de outro modelo de sensor de temperatura ou sua implementação em um micro - controlador cuja a entrada analógica possua maior precisão do que o adotado ou ainda, a utilização de um regulador de tensão para alimentação do sensor de temperatura, visando assim uma maior estabilidade. $O$ método de desenvolvimento adotado, roteiro crítico de projeto com descrito por Delgado Neto, Alkmin e Silva, Cabral Vieira e Dedini (2010), trouxe passos lógicos e necessários ao desenvolvimento do projeto. As etapas e as ferramentas utilizadas possibilitaram que, uma vez idealizado o produto a ser projetado, este pode ser comparado a outros similares disponíveis no mercado, possibilitou que fossem realizadas pesquisas com o público alvo do sistema e assim descobrir necessidades e novas funcionabilidades a serem adotadas. Auxiliou também para que fossem listados e depois definidos todos os possíveis sistemas que poderiam ser adotados para se chegar aos objetivos necessários. Depois, numa próxima etapa, desenvolver os métodos matemáticos e lógicos para funcionamento de todo o sistema e depois foi um auxílio para que fossem previstos o desempenho do que foi adotado e se caso necessário fossem revistos. E numa próxima etapa, a geração de toda a documentação necessária à produção do que foi projetado.

\section{REFERÊNCIAS BIBLIOGRAFICAS}

DELGADO NETO, Geraldo Gonçalves; DE ALKMIN E SILVA, Ludmila Corrêa; CABRAL VIEIRA, Vivianne; DEDINI, Franco Giuseppe. Aplicação de Roteiro Crítico de Projetos em Curso de Graduação. Revista de Ensino de 
Engenharia, v.29, n.2, p. 35-42, 2010. Disponível em:

HTTP://www.abenge.org.br/revista/index.php/abenge/article/download. Acesso em: 16 mar. 2013.

MARQUEZINI FILHO, Paulo Afonso. Sistema de Monitoramento Remoto de Desempenho e Avaliação Física de Atletas. Faculdade de Jaguariúna, 2013.

BRAGA, Egídio Alberto. Instrumentação Industrial. Rio de Janeiro: Editora Interciência, 2003.

SANDRINI LUZ, Carlos Eduardo. Criação de Sistemas Supervisório em Visual C\# 2010. São Paulo: Editora Érica, 2012.

TRISTHER, K. Medida e Avaliação em Educação Física e Esportes. São Paulo: Editora Manole, 2003.

FIGUEIREDO, Lígia J.; GAFANIZ, Ana R.; LOPES, Gustavo S.; PEREIRA, Ruben. Aplicações de Acelerómetros, 2007. Monografia - Engenharia Biométrica do Instituto Superior Ténico, Av. Rovisco Pais, Lisboa, Portugal. Disponível em: HTTP://nebm.ist.utl.pt/repositorio/download/375. Acesso em: 18 mar. 2013.

BRAGA, Newton C. O que são frequencímetros. [S.1.], 20--. Disponível em: HTTP://www.newtoncbraga.com.br/index.php/instrumentacao/108-artigosdiversos/2747-ins133. Acesso em: 18 mar. 2013.

PRADA, Rodrigo. O que é um acelerômetro. [S.1.], 2009. Disponível em: HTTP://www.tecmundo.com.br/curiosidade/2652-o-que-e-um-acelerometrohtm?utm source=outbrain\&utm medium=recomendados\&utm campaign=outb rain=obinsite. Acesso em: 26 mar. 2013.

DECICINO, Ronaldo. GPS: Sistema de Posicionamento Global tem diferentes utilidades. [S.1.], 2009. Disponível em:

HTTP://educacao.uol.com.br/disciplinas/geografia/gps-sistema-deposicionamento-global-tem-diferentes-utilidades.htm. Acesso em: 26 mar. 2013.

GURGEL, Anderson. Esporte - Pátria das bicicletas, quimonos, raquetes e chuteiras. Revista Desafios do Desenvolvimento, IPEA - Instituto de Pesquisa Econômica Aplicada, São Paulo, 2011. Disponível em:

HTTP://www.ipea.gov.br/desafios/index.php?option=com content\&view=article \&id=1149:reportagens-materias\&ltemid=39. Acesso em: 22 abr. 2013.

Dossiê Esporte. Disponível em: http://globosat. globo. com/sportv/hotsite/dossie /dossie esporte. htm. Acesso em 22 abr. 2013.

FERNANDES, Jorge. O que é um programa (software)?. [S.1.], 2002.

Disponível em :

HTTP://www.cic.unb.br/ jhcf/MyBooks/iess/software/oqueehsoftware.html. Acesso em: 29 mar. 2013. 


\section{PAIOLA, Carlos E.G.. O papel do supervisório no atual contexto}

tecnológico. Revista Intech, n. 132, p.6-18, 20--.

Nike+ Running ou Adidas MiCoach: Qual APP é melhor?.

http://www.redbull.com.br/cs/Satellite/pt BR/Article/Nike-Running-ou-AdidasmiCoach-qual-app-\%C3\%A9-melhor-021243317269572. Acesso em: 14 set. 2013.

\section{Sobre os autores}

Paulo Afonso Marquezini Filho

Engenheiro de Controle e Automação

paulo marquezini@hotmail.com

Prof. Dr. Geraldo Gonçalves Delgado Neto

Possui graduação em Desenho Industrial Projeto do Produto pela Universidade Estadual Paulista Júlio de Mesquita Filho (2001), mestrado, doutorado e pósdoutorado em Engenharia Mecânica pela Universidade Estadual de Campinas (2005, 2008 e 2012, respectivamente), Fez parte da equipe de desenvolvimento de projeto de produto no LabSIn (Laboratório de Sistemas Integrados) - Unicamp. Professor Visitante UNICAMP - FEAGRI ate janeiro de 2015. Atuou em outras parcerias importantes: CTI - Centro da Tecnologia da Informação e Technische Universitat Darmstadt. Assessor Pedagógico do curso de Engenharia de Produção da Faculdade Jaguariúna (FAJ), Coordenador da área de pesquisa Ciências Exatas e Tecnológicas do Núcleo de Estudos e Pesquisas Interdisciplinar (NEPI) Graduação e Pós-graduação Faculdades Jaguariúna (FAJ) e Max Planck. Professor Titular em Metodologia de Projeto do Produto e participa do Conselho Editorial da Revista INTELLECTUS - Revista Acadêmica Digital da FAJ. Possui experiência em Design Projeto do Produto, Engenharias de Produção, de Controle e Automação e Mecânica. Trabalha em áreas relacionadas à gestão da inovação, gestão da qualidade, metodologia e gerenciamento de projeto do produto, manufatura, ergonomia, acessibilidade e design universal (projeto inclusvo). Possui experiência em Design Projeto do Produto, Design Universal, Promoção da Saúde, Engenharias de Produção, de Controle e Automação e Mecânica. Professor e pesquisador pela Faculdade Jaguariúna FAJ, Coordenador de pesquisa NEPI da área de exatas e tecnológicas. Coordenador do Grupo de Estudo de Desenvolvimento de Alta Tecnologia - GEDAi (Design Universal e tecnologia). Coordenador do Grupo de Estudo de Práticas Pedagógicas para Eng. De Produção - GEPPEP (Metodologias de aprendizagem e práticas da engenharia).Coord. do Grupo de Estudo de Engenharia e Arte - MOMENTO (através da cultura criar vínculos entre alunos e a Faculdade).

ggeraneto@gmail.com 